УДК 556.332.52(571.1)

\title{
ИЗОТОПНО-ГЕОХИМИЧЕСКИЕ ОСОБЕННОСТИ ПРОЯВЛЕНИЯ СЛАБОРАДОНОВЫХ ВОД «ИНСКИЕ ИСТОЧНИКИ» (ЮГ ЗАПАДНОЙ СИБИРИ)
}

\author{
Новиков Дмитрий Анатольевич1,2, \\ NovikovDA@ipgg.sbras.ru
}

Копылова Юлия Григорьевна 3 , unpc_voda@mail.ru

Вакуленко Людмила Галериевна ${ }^{1,2}$, VakylenkoLG@ipgg.sbras.ru

\section{Сухорукова Анна Федоровна ${ }^{1,2}$, SukhorukovaAF@ipgg.sbras.ru}

\author{
Пыряев Александр Николаевич4,2, \\ pyrayev@igm.nsc.ru
}

\author{
Максимова Анастасия Алексеевна², \\ rock.nastaya64@gmail.com
}

Дульцев Федор Федорович 1 , DultsevFF@ipgg.sbras.ru

\section{Черных Анатолий Витальевич1, ChernykhAV@ipgg.sbras.ru}

1 Институт нефртегазовой геологии и геофизики им. А.А. Трофимука СО РАН, Россия, 630090, г. Новосибирск, пр. Академика Коптюга, 3/6.

2 Новосибирский национальный исследовательский государственный университет, Россия, 630090, г. Новосибирск, ул. Пирогова, 1.

3 Национальный исследовательский Томский политехнический университет, Россия, 634050, г. Томск, пр. Ленина, 30.

4 Институт геологии и минералогии им. В.С. Соболева СО РАН, Россия, 630090, г. Новосибирск, пр. Академика Коптюга, 3

\begin{abstract}
Актуальность исследования заключается в получении первых изотопно-геохимических данных о природных водах и вмещающих горных породах проявления слаборадоновых вод «Инские источники».

Цель: изучить особенности химического состава природных вод и водовмещающих пород и получить первые сведения по суммарной á- и $\beta$-активности природных вод, активности ${ }^{222} R n$ и изотопному составу $\delta D, \delta^{18} \mathrm{O}, \delta^{13} \mathrm{C},{ }^{234} \mathrm{U},{ }^{238} \mathrm{U},{ }^{226} \mathrm{Ra} u^{228} \mathrm{Ra}$.

Методы. Отбор проб выполнялся в соответствии с общепринятыми методиками. Лабораторное изучение химического состава методами титриметрии, ионной хроматографрии, масс-спектрометрии с индуктивно связанной плазмой проводилось в ПНИЛ гидрогеохимии ИШПР ТПУ. Анализ комплекса изотопных соотношений $\delta D, \delta^{18} \mathrm{O}, \delta^{13} C_{D I C} 80 \partial$ и растворенного неорганического углерода проводился в центре коллективного пользования Института геологии и минералогии им. В.С. Соболева CO PAH с помощью прибора Isotope Ratio Mass Spectrometer Finnigan ${ }^{T M}$ MAT 253. Данные по суммарной '́- и $\beta$-активности природных вод, а также активностях ${ }^{234} \mathrm{U},{ }^{238} \mathrm{U},{ }^{226} \mathrm{Ra}$ u ${ }^{228} \mathrm{Ra}$ получены с помощью гамма-спектрометрии и альфраспектрометрии (после предварительной радиохимической пробоподготовки).

Результаты. В 2019 г. в 35 км от г. Новосибирска, вдали от известных гранитных массивов, открыто проявление слаборадоновых вод "Инские источники», относящееся к водам зоны региональной трещиноватости. В настоящей работе приводятся первые результаты их геохимических исследований. Установлено, что воды источников умеренно пресные $\mathrm{HCO}_{3} \mathrm{Mg}_{\text {- }}$ Са состава с величиной общей минерализации от 389 до 536 мг/дм³ с содержаниями кремния 4,14-8,61 ме/дм³. Они характеризуются рН от нейтральных до слабощелочных (7,1-8,4), окислительной геохимической обстановкой с Eh +205,3-+231,8 мB и

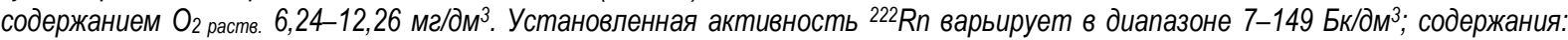

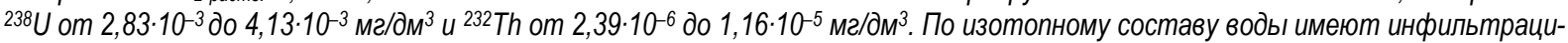
онное происхождение. Диапазон значений $\delta^{18} \mathrm{O}$ в водах меняется от $-17,1$ до $-16,7 \%$ со значениями $\delta D$ от $-128,4$ до -126,2 \%о и вариацией $\delta^{13} \mathrm{C}$ от -13,1 до -10,3\%. Вмещающие породы представлены глинистыми сланцами темно-серого (до черного), иногда серого цвета, с небольшой примесью алевритового, песчано-алевритового материала. Изотопный состав кальцита вмещающих пород характеризуется близкими значениями: $\delta^{13} \mathrm{C}$ варьирует от -3,1 до -2,7 \%, $\delta^{18} \mathrm{O}-$ om 17,2 до 18,4\%. Выветрелые глинистые сланцы характеризуются облегчением по $\delta^{13} \mathrm{C}\left(\partial \mathrm{\partial}-11,0 \%\right.$ и и по $\delta^{18} \mathrm{O}(\partial 0$ 13,9 \%o). Также эти образцы по результатам геохимических исследований характеризуется существенным снижением (в несколько раз) содержания всех элементов-примесей (кроме U), свидетельствующим об активном взаимодействии вод с вмещающими породами.
\end{abstract}

\section{Ключевые слова:}

Радоновые воды, стабильные изотопы, уранизотопное отношение, уран, радий, радон, новое проявление радоновых вод «Инские источники», Новосибирская городская агломерация, Западная Сибирь.

\section{Введение}

Новосибирская городская агломерация (НГА) активно развивается на протяжении последнего века. В настоящее время темпы ввода нового жилья для населения достигают 1 млн м² в год и более. К сожалению, застройка новых районов приводит к вырубке лесных массивов и деградации природных ландшаф- тов. В этой связи возникает острая необходимость в организации и обустройстве туристическорекреационных зон для отдыха городского населения. Одним из важнейших ресурсов для их успешного развития являются природные воды (речные системы), обладающие большой эстетической ценностью. При этом одной из основных опасностей в пределах НГА 
является широкое развитие радоновых вод, имеющих природное происхождение. OOH (комитет UNSCEAR) оценил, что воздействие естественных источников вносит более 98 \% дозы облучения населения. Естественная радиоактивность природных вод вызывает в мире большой интерес [1-22].

Природные радионуклиды попадают в организм человека в основном при дыхании $\left({ }^{222} \mathrm{Rn},{ }^{220} \mathrm{Rn}\right.$ и их продукты распада), с питьевой водой и пищей $\left({ }^{238} \mathrm{U},{ }^{232} \mathrm{Th}\right.$, ${ }^{226} \mathrm{Ra}$ и $\left.{ }^{222} \mathrm{Rn}\right)$. Радон $\left({ }^{222} \mathrm{Rn}\right)-$ химически инертный и очень подвижный газ, продукт распада урана $\left({ }^{238} \mathrm{U}\right) . \mathrm{OH}$ является основным источником воздействия ионизирующего излучения на население в большинстве стран, считаясь второй наиболее распространенной причиной рака легких после курения сигарет. В этой связи основная цель настоящего исследования заключена в выявлении изотопно-геохимических особенностей подземных вод и вмещающих пород одного из проявлений радоновых вод НГА - «Инских источников», расположенных на расстоянии около 35 км от известных гранитных массивов.

\section{Материалы и методы}

Ввиду незначительной глубины залегания источников эманации радона (гранитных массивов) в природных водах НГА отмечается его активность, достигающая в некоторых объектах до 43764 Бк/дм ${ }^{3}$. В августе 2019 г. во время полевых работ, связанных с изучением радоновых вод НГА, в результате последующих лабораторных исследований была выявлена повышенная активность радона в четырех естественных выходах природных вод (источниках) в долине реки Иня (рис. 1). Источники были повторно опробованы в ноябре этого же года. Активность радона $\left({ }^{222} \mathrm{Rn}\right)$ составила до 149 Бк/дм ${ }^{3}$. Интересным фактом является то, что впервые открытое проявление слаборадоновых вод «Инские источники» расположено вдали от известных гранитных массивов города Новосибирска и его окрестностей, с которыми связаны более десяти месторождений минеральных радоновых вод - «Заельцовское», «Горводолечебница» и другие [23-31].

Во время экспедиционных работ непосредственно на источниках были определены нестабильные параметры (pH, Eh, температура, содержание растворенного $\mathrm{O}_{2}, \mathrm{HCO}_{3}{ }^{-}$) с помощью полевой гидрогеохимической лаборатории и полевого оборудования (Hanna НІ9125, кислородомер АКПМ-1-02Л), общая минерализация вод (кондуктометр S3-Field kit Seven2Go, Mettler Toledo). Измерение содержаний радона в природных водах проводилось с помощью комплекса «Альфарад плюс» в лаборатории гидрогеологии осадочных бассейнов Сибири ИНГГ СО РАН. Последующее лабораторное изучение химического состава методами титриметрии, ионной хроматографии, массспектрометрии с индуктивно связанной плазмой (ИСП) проводилось в ПНИЛ гидрогеохимии ИШПР ТПУ (аналитики О.В. Чеботарева, Н.В. Бублий, А.С. Погуца, В.В. Куровская, К.Б. Кривцова, Л.А. Ракул).

Анализ комплекса величин $\delta \mathrm{D}, \delta^{18} \mathrm{O}, \delta^{13} \mathrm{C}_{\mathrm{DIC}}$ для вод и растворенного неорганического углерода (Dissolved Inorganic Carbon (DIC)) проводился в центре коллективного пользования ИГМ СО РАН с помощью прибора Isotope Ratio Mass Spectrometer Finni$\operatorname{gan}^{\mathrm{TM}}$ MAT 253, снабженного приставками пробоподготовки H/Device (для анализа $\delta \mathrm{D}$ ) и GasBench II (для анализа $\delta^{18} \mathrm{O}$ и $\left.\delta^{13} \mathrm{C}_{\text {DIC }}\right)$. Значения $\delta^{13} \mathrm{C}_{\mathrm{DIC}}, \delta \mathrm{D}$ и $\delta^{18} \mathrm{O}$ измерялись относительно мировых стандартов: VSMOW2; SLAP2; GISP - для анализа водорода и кислорода; NBS-18; NBS-19 - для анализа $\delta^{13} \mathrm{C}_{\text {DIC. }}$ Ошибка определения изотопного состава стандартов по углероду и кислороду - не более 0,1 \%, по водороду - не более $2 \%$. Данные по суммарной $\alpha-$ и $\beta$ активности природных вод, а также активностям ${ }^{234} \mathrm{U}$, ${ }^{238} \mathrm{U},{ }^{226} \mathrm{Ra}$ и ${ }^{228} \mathrm{Ra}$ получены с помощью гаммаспектрометрии и альфа-спектрометрии (после предварительной радиохимической пробоподготовки).

Нами также впервые были выполнены комплексные исследования водовмещающих пород с применением современных аналитических методов: поляризационная и сканирующая электронная микроскопия с энергодисперсионным спектрометром, рентгеноструктурный, ИСП-МС, изотопный анализы.

\section{Изотопно-геохимические особенности природных вод}

Изученные воды четырех «Инских источников» относятся к водам зоны региональной трещиноватости. Они умеренно пресные $\mathrm{HCO}_{3} \mathrm{Mg}-\mathrm{Ca}$ состава с величиной общей минерализации от 389 до 536 мг/дм ${ }^{3}$, содержанием кремния 4,14-8,61 мг/дм ${ }^{3}$ и органического углерода $0,3-1,5$ мг/дм³. Отмечается рост величины общей минерализации от августа к ноябрю по всем изученным источникам на 24-89 мг/дм ${ }^{3}$, за исключением № 2, который оказался в это время сухим. Геохимические параметры (pH, Eh и $\left.\mathrm{O}_{2}\right)$ контролируются в первую очередь условиями залегания природных вод и характером их водообмена, что хорошо иллюстрируется полученными данными. Воды характеризуются $\mathrm{pH}$ от нейтральных до слабощелочных $(7,1-8,4)$, окислительной геохимической обстановкой с Eh +205,3 $+231,8$ мВ с содержанием $\mathrm{O}_{2}$ раств. 6,24-12,26 мг/дм³. В источнике № 3 выявлена значительная связь с поверхностными водами, что проявляется слабощелоч-

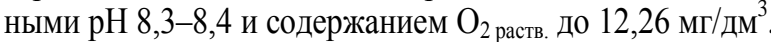

Трещинно-жильные радоновые воды Новосибирского гранитоидного массива характеризуются средними отношениями $\mathrm{Ca} / \mathrm{Na}=3,6 ; \mathrm{Ca} / \mathrm{Mg}=2,9 ; \mathrm{Ca} / \mathrm{Si}=14,0$; $\mathrm{Mg} / \mathrm{Si}=4,9 ; \mathrm{Na} / \mathrm{Si}=3,9 ; \mathrm{Si} / \mathrm{Na}=0,3 ; \mathrm{rNa} / \mathrm{rCl}=1,7$ и $\mathrm{SO}_{4} / \mathrm{Cl}=2,0$. Источники же значительно отличаются по величинам всех геохимических коэффициентов. Так, $\mathrm{Ca} / \mathrm{Na}=13,2$; $\mathrm{Ca} / \mathrm{Mg}=6,3 ; \mathrm{Ca} / \mathrm{Si}=13,7 ; \mathrm{Mg} / \mathrm{Si}=2,2 ; \mathrm{Na} / \mathrm{Si}=1,1 ; \mathrm{Si} / \mathrm{Na}=1,0$; $\mathrm{rNa} / \mathrm{rCl}=2,0$ и $\mathrm{SO}_{4} / \mathrm{Cl}=2,5$. Более чем десятикратное пропорциональное превышение концентраций кальция и натрия над концентрациями кремния в водах источников свидетельствует об алюмосиликатном составе водовмещающих отложений. По результатам геофизических исследований (метод сопротивлений в модификации электротомографии) установлена ослабленная трещиноватая зона между источниками № 2 и 3, а также высокоомный объект со значениями УЭС 1000-4000 Ом•м, что может предполагать наличие дайки спессартитов, кварцевых монцодиоритпорфиритов, широко развитых в изучаемом районе. 


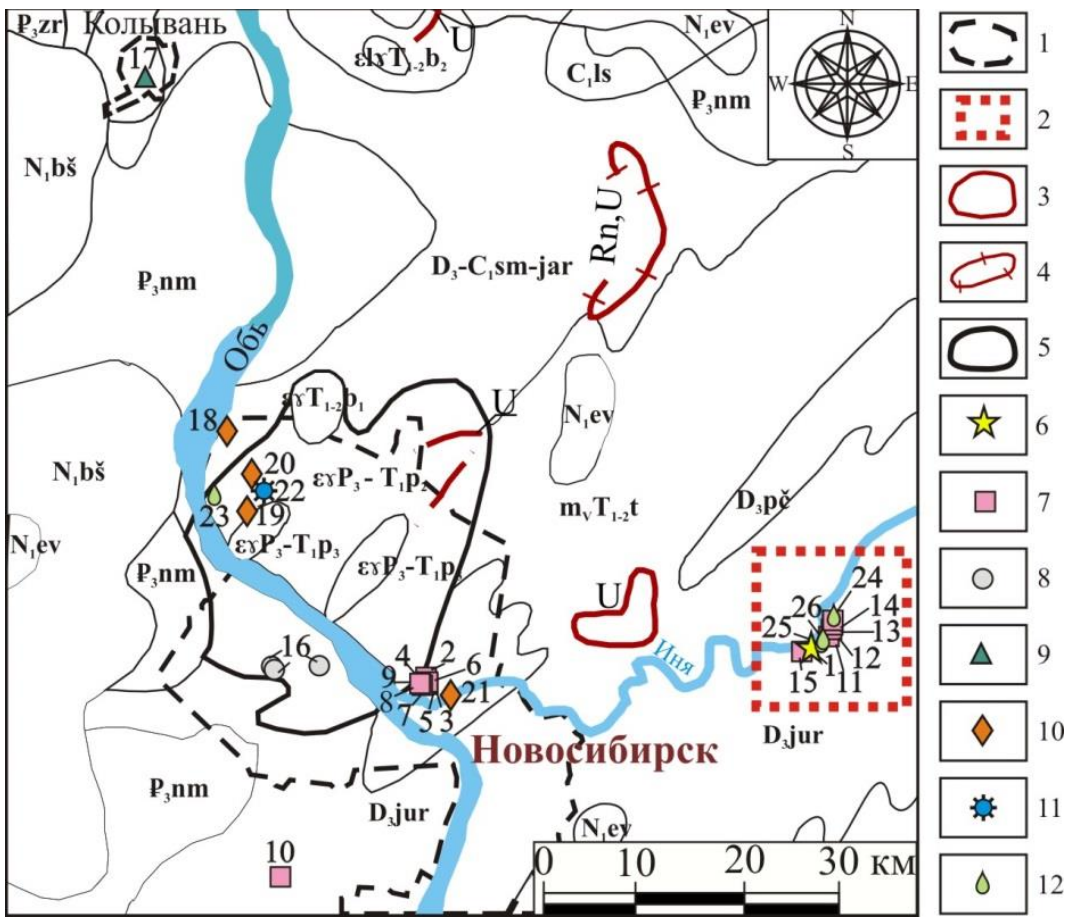

Pис. 1. Местоположение изученных объектов. Границы: 1 - административные, 2 - Инских источников; аномалий: 3 -U в рыхлых отложениях, 4 -Rn, U гидрогеохимических; 5 - Новосибирский гранитный массив; Типы вод по условиям залегания: 6 - грунтовые воды покровных карбонатных отложений (группа I): 1 - колодец; 7 воды зоны региональной трещиноватости (группа II): карьер Борок: 2 - техногенное озеро № 1, 3 - техногенное озеро № 2, 4 - техногенное озеро № 3, 5 - источник № 1, 6 - источник № 2 (водопад), 7 - источник № 3 (водопад), 8 -источник № 4 (водопад), 9 - источник № 5 (водопад), 10 - Святой источник, с. Верх-Тула; «Инские источники»: 11 - источник № 1, 11 - источник № 2, 13 - источник № 3, 14 - источник № 4, 15 скважсина глубиной 80 м; 8 - трещинно-жильные воды гранитоидов (группа III): 16 - скважина в Городской больниие № 34, г. Новосибирск; 9 - трещинно-жсильные воды гранитоидов в условиях антропогенного влияния (группа IV): 17 - скважина глубиной 18 м в Покровском Александро-Невском женском монастыре, p.n. Кольввань; 10 - поверхностные воды (группа V): 18 - протока р. Оби, 19 - р. 2-я Ельцовка, 20 - Озеро X, истоки р. 2-я Ельцовка, 21 - р. Иня; 11 - поверхностные воды, подверженные влиянию процессов континентального засоления (группа VI): 22 - p. 2-я Ельиовка, зарегулированное русло по ул. Георгия Колонда; 12 - поверхностные воды в условиях антропогенного влияния (группа VII): 23 - р. Обь, Заельцовский бор; 24 - р. Иня, напротив источника № 4; 25 - p. Иня, ниже источника № 1; 26 - p. Иня, ближе к источнику № 1

Fig. 1. Location of the studied objects. Boundaries: 1 - administrative, 2 - study area - «Inskie springs»; anomalies: $3-U$ in soft sediments, 4 - hydrogeochemical $R n$ and $U ; 5$ - boundaries of the Novosibirsk granite massif. Water types according to occurrence conditions: 6 - groundwater of drape carbonate (group I): 1 -well; 7 -waters of the zone of regional fracturing (group II): Borok quarry: 2 - technogenic lake no. 1, 3-technogenic lake no. 2, 4-technogenic lake no. 3, 5 - spring no. 1, 6 - spring no. 2 (waterfall), 7 - spring no. 3 (waterfall), 8 - spring no. 4 (waterfall), 9 spring no. 5 (waterfall), 10 - Svyatoy spring, v. Verkh-Tula; Inskie springs: 11 - no. 1, 12 - no. 2, 13 - no. 3, 14 no. 4, 15 - well (depth $80 \mathrm{~m}$ ); 8 -fractured vein waters of granitoids (group III): 16 - well in the Novosibirsk General Hospital no. 34; 9 - fissure-vein waters of granitoids under conditions of anthropogenic influence (group IV): 17 - well (depth $18 \mathrm{~m}$ ) in the Pokrovskaya Alexander Nevsky Convent, Kolyvan; 10 - surface waters (group V): 18 Ob river, 19 - 2-nd Yeltsovka river, 20 - lake X, river head of 2-nd Yeltsovka, 21 - r. Inya; 11 - surface waters affected by continental salinization processes (group VI): 22 - river 2-nd Yeltsovka in technogenic stream bed; 12 surface waters under conditions of anthropogenic influence (group VII): 23 - Ob river, Zaeltsovsky Bor; 24 - Inya river, opposite the spring no. 4; 25 - Inya river, below the spring no. 1; 26 - Inya river, closer to the Inskie springs (no. 1)

В сравнении с ними в Святом источнике в с. ВерхТула, также приуроченном к отложениям юргинской свиты ( $\mathrm{D}_{3}$ jur), концентрации кальция только вдвое превышают концентрации натрия при соизмеримых отношениях натрия и магния к кремнию. Его отличают следующие значения коэффициентов: $\mathrm{Ca} / \mathrm{Na}=2,7$; $\mathrm{Ca} / \mathrm{Mg}=2,4 ; \mathrm{Ca} / \mathrm{Si}=15,9 ; \mathrm{Mg} / \mathrm{Si}=7,2 ; \mathrm{Na} / \mathrm{Si}=6,0 ; \mathrm{Si} / \mathrm{Na}=0,2 ;$ $\mathrm{rNa} / \mathrm{rCl}=22,3$ и $\mathrm{SO}_{4} / \mathrm{Cl}=3,0$. Воды Святого источника можно считать фоновыми. Они собственно пресные $\mathrm{HCO}_{3} \mathrm{Na}-\mathrm{Mg}-\mathrm{Ca}$ состава с величиной общей минера- лизации от 587 до $686 \mathrm{мг} /$ дм $^{3}$, содержанием кремния 4,07-6,62 мг/дм ${ }^{3}$ и органического углерода 0,4-1,7 мг/дм ${ }^{3}$. Воды нейтральные $\mathrm{pH}(7,4-7,5)$ с восстановительными условиями геохимической среды с Eh от

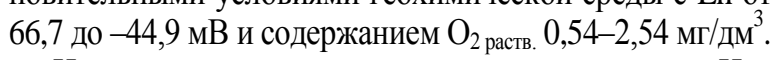

Изучение микрокомпонентного состава вод «Инских источников» показало корреляцию всех основных положительных и отрицательных пиков, за исключением урана и палладия, по сравнению с вмещающими породами. На спектре распределения хи- 
мических элементов в водах наиболее высокие содержания (мг/дм $\left.{ }^{3}\right)$ отмечаются у: $\mathrm{Sr}$ (до 0,54), $\mathrm{Fe}$ (до $0,18), \mathrm{B}$ (до 0,03$), \mathrm{Ba}($ до 0,02$), \mathrm{Al}$ (до $\left.7,9 \cdot 10^{-2}\right), \mathrm{Br}$ (до $5,6 \cdot 10^{-2}$ ), I (до $8,1 \cdot 10^{-3}$ ), U (до $4,1 \cdot 10^{-3}$ ), а наиболее низкие у $\mathrm{Pd}$ (до $8,4 \cdot 10^{-6}$ ), Tm (до $1,2 \cdot 10^{-6}$ ), In (до $\left.7,6 \cdot 10^{-7}\right)$ и Ві (до $\left.6,1 \cdot 10^{-7}\right)$. В августе наблюдался рост концентраций от первого источника к четвертому по $\left(\right.$ мг/дм $\left.{ }^{3}\right): \mathrm{Br}$ до $4,2 \cdot 10^{-2}, \mathrm{Li}$ до $7,6 \cdot 10^{-3}$, U до $4,1 \cdot 10^{-3}$, $\mathrm{Cu}$ до $3,9 \cdot 10^{-4}$ и Th до $3,6 \cdot 10^{-6}$. В ноябре отмеченная тенденция сохраняется у $\mathrm{Br}, \mathrm{Li}$ и $\mathrm{U}$.

Активность ${ }^{222} \mathrm{Rn}$ в «Инских источниках» изменяется в диапазоне от 7 до 149 Бк/дм³. Его вариация в источниках имеет следующий вид (Бк/дм³): № 1 (66-112), № 2 (47-56), № 3 (7-20), № 4 (65-149). Связь с поверхностными водами в источнике № 3 подтверждается низкой активностью радона. Суммарная $\alpha$ активность вод составляет 3-4 мБк/дм³, а $\beta$-активность 11-15 мБк/дм ${ }^{3}$. Природные радионуклиды содержатся в водах в следующих пределах $\left(\right.$ мг/дм $\left.{ }^{3}\right):{ }^{238} \mathrm{U}$ от $2,83 \cdot 10^{-3}$ до $4,13 \cdot 10^{-3}$; ${ }^{232}$ Th от $2,39 \cdot 10^{-6}$ до $1,16 \cdot 10^{-5}$ и ${ }^{226} \mathrm{Ra}$ от $3,83 \cdot 10^{-10}$ до $4,93 \cdot 10^{-10} \cdot{ }^{232} \mathrm{Th} /{ }^{238} \mathrm{U}$ отношение в водах варьирует в интервале от $8,85 \cdot 10^{-4}$ до $3,61 \cdot 10^{-3}$, а в породах составляет 0,3-27,8, при среднем значении 14,0. Активность изотопов урана и радия составляет у $\left(\mathrm{мБ \kappa} / \mathrm{дm}^{3}\right):{ }^{234} \mathrm{U}$ $(117-124),{ }^{238} \mathrm{U}(38-48),{ }^{226} \mathrm{Ra}(14-18)$ и ${ }^{228} \mathrm{Ra}(5,7-7,4)$. Уранизотопное отношение $(\gamma){ }^{234} \mathrm{U} /{ }^{238} \mathrm{U}$ в «Инских источниках» варьирует в интервале от 2,6 до 3,2, что говорит о неглубокой циркуляции этих вод по сравнению с водами Святого источника в с. Верх-Тула, в которых $\gamma=1,3$.

Анализ величин $\delta^{18} \mathrm{O}, \delta \mathrm{D}$ вод в комплексе с $\delta^{13} \mathrm{C}$ растворенной в водах углекислоты позволяет ответить на широкий спектр важных вопросов: генезис вод, их взаимодействие с окружением (газами и горными породами), протекание процессов водообмена [32]. При интерпретации данных по стабильной изотопии кислорода и водорода обычно оперируют глобальной (Global Meteoric Water Line - GMWL) и локальной (Local Meteoric Water Line - LMWL) линиями метеорных вод. Первая, предложенная Г. Крейгом [33], описывает глобальное среднегодовое соотношение между $\delta \mathrm{D}$ и $\delta^{18} \mathrm{O}$ (рис. 2, $a$ ) в природных метеорных водах уравнением $\delta \mathrm{D}=8,0 \cdot \delta^{18} \mathrm{O}+10$. Линия LMWL, представляющая соотношение относительных концентраций указанных изотопов в заданной области, может существенно отличаться от GMWL. На момент исследования данные по значениям $\delta \mathrm{D}$ и $\delta^{18} \mathrm{O}$ вод НГА очень ограничены $[34,35]$. Они могут быть описаны уравнением $\delta \mathrm{D}=7,5 \cdot \delta^{18} \mathrm{O}-5$. Изотопный анализ отобранных образцов вод показал довольно широкую вариацию значений $\delta \mathrm{D}\left(\right.$ от -139 до $-113 \%$ и $\delta^{18} \mathrm{O}$ (от -19 до $-15 \%$ \%). Для всех исследованных вод пара $\delta \mathrm{D}-\delta^{18} \mathrm{O}$ располагается между локальной и глобальной линиями метеорных вод (рис. 2, a). Это позволяет сделать вывод об инфильтрационном происхождении природных вод исследуемого региона.
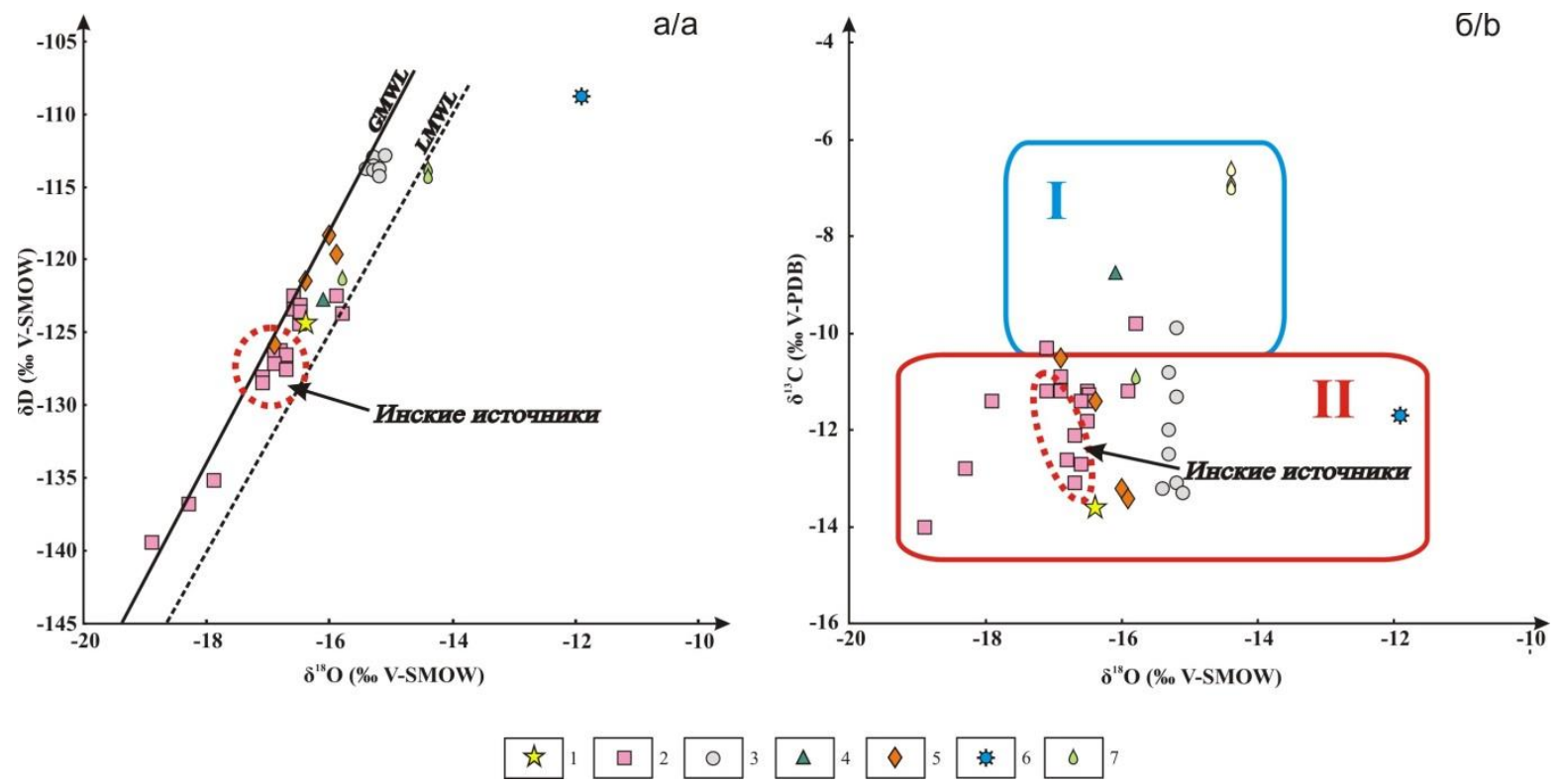

Pис. 2. Изотопный состав Н и $О($ (a/a), С и $О(6 / b)$ природных вод НГА: 1 - грунтовые воды покровных карбонатных отложений; 2 - воды зоны региональной трещчиноватости; 3 - трещинно-жильные воды гранитоидов; 4 трещинно-жильные воды гранитоидов в условиях антропогенного влияния; 5 - поверхностные воды; 6 - поверхностные воды, подверженные влиянию процессов континентального засоления; 7 - поверхностные воды в условиях антропогенного влияния

Fig. 2. Isotopic composition of $\delta D$ and $\delta^{18} O(a / a), \delta^{13} C$ and $\delta^{18} O(6 / b)$ in natural waters of Novosibirsk city agglomeration: 1 - groundwater of drape carbonate; 2 - waters of the zone of regional fracturing; 3 -fractured vein waters of granitoids; 4 - fissure-vein waters of granitoids under conditions of anthropogenic influence; 5 - surface waters; 6 surface waters affected by continental salinization; 7 - surface waters under conditions of anthropogenic influence

Данные по изотопному составу растворенного неорганического углерода вод, $\delta^{13} \mathrm{C}_{\mathrm{DIC}}$, позволяют сделать выводы о взаимодействии вод с окружающей средой, обнаружить вероятные источники DIC в водах, среди которых можно выделить гидролиз карбонат-содержащих пород, так называемый почвенный 
$\mathrm{CO}_{2}$, атмосферный диоксид углерода, а также органическую (биогенную) углекислоту [36,37]. Значения $\delta^{13} \mathrm{C}_{\text {DIC }}$ исследованных вод НГА варьируют в диапазоне от $-9,0$ до $-14,0 \%$ (рис. 2, б). Согласно данным [38], значение $\delta^{13} \mathrm{C}$ атмосферного $\mathrm{CO}_{2}$ в широтах Новосибирской области, в зависимости от времени года, колеблется от $-8,0$ до -9,0 \%о. С учетом этого значения и обеднения соотношения $\delta^{13} \mathrm{C}$ тяжелым изотопом на 1,2 \% за счет фракционирования при переходе из атмосферного $\mathrm{CO}_{2}$ в водорастворенную форму [39] ожидаемое значение $\delta^{13} \mathrm{C}_{\text {DIC }}$ дождевой воды должно варьировать в диапазоне от $-9,2$ до -10,2 \%. Очевидно, что ряд образцов (область I), представленных в настоящей работе, попадает в эти рамки и происхождение DIC этих вод, по-видимому, носит атмосферный характер.

Между тем большая часть представленных вод имеет более легкие изотопные отношения $\mathrm{C}_{\mathrm{DIC}}$ (область II). Наиболее вероятным источником легких изотопов углерода в поверхностных водах представляется почвенная углекислота, сформированная в ходе биогенного распада углерод-содержащих органических остатков (в основном, растительного происхождения), содержащихся в почвах. В зависимости от доминирования растений с определенным типом фотосинтеза (C3 или C4) в исследуемом ареале изотопный состав углерода остатков этих растений может сильно варьировать. Согласно данным $[36,40]$, значения $\delta^{13} \mathrm{C}_{\mathrm{DIC}}$ в диапазоне от -9 до -14 \%о характерны для вод, взаимодействующих с силикатными и карбонатными породами, содержащими остатки растений типа С3.

\section{Изотопно-геохимические особенности} вмещающих пород

Вмещающие отложения впервые макроскопически описаны в составе верхней части верхнедевонской Инской формации, так называемых Шиферных слоев, в монографии А.И. Гусева [41]. Согласно опубликованным материалам, более детальных минералогопетрографических и геохимических исследований по указанному объекту не проводилось.

Вмещающие породы представлены глинистыми, редко известково-глинистыми сланцами темно-серого (до черного), иногда серого (более светлые разновидности выветрелого облика) цвета, с небольшой примесью алевритового, песчано-алевритового материала (от первых \% до $15 \%$ ) и тонко-микрокристаллического кальцита (первые \%, иногда до 35-40 \%). В разной степени (в основном незначительно) проявлены тонкодисперсное ОВ и пирит. Встречаются редкие включения окислов-гидроокислов железа и пятнистое ожелезнение вдоль плоскостей сколов. Характерны субпослойные и наклонные тонкие трещинки, выполненные кальцитом. В составе сланцев преобладающая глинистая часть представлена хорошо окристаллизованными слюдой мусковитового типа и, вероятно, парагонитом (от 25 до 45 \%), Mg, иногда Fe-Mg хлоритом (5-20\%), установлены также кварц (20-35\%), полевые шпаты (10-25 \%), кальцит. В качестве незначительных примесей отмечаются сидерит (?), пирит, пирротин, псиломелан (?), гранат, амфибол, цеолит (филлипсит).
Второй тип вмещающих пород представлен известняком (известковым туфом) светлым коричневато-серым, участками белесым, сильно пористым, натечной текстуры, микритовым, участками яснокристаллическим, с неравномерно распределенной незначительной примесью мелкоалевритового материала. По результатам электронномикроскопических исследований в составе примеси установлены альбит, калиевый полевой шпат, кварц, амфибол, апатит, эпидот, рутил, титанит, ильменит, магнетит, хлорит. Кальцит в почковидных микритовых образованиях имеет чистый состав, а в яснокристаллических участках в нем появляется небольшая примесь $\mathrm{Mg}$ (рис. 3, А, Б). В известково-глинистом сланце в кальците отмечена примесь $\mathrm{Fe}, \mathrm{Mg}, \mathrm{Mn}, \mathrm{Sr}$ (рис. 3, B).

Изученный изотопный состав $\mathrm{C}$ и $\mathrm{O}$ кальцита вмещающих пород характеризуется близкими значениями для большей части образцов: $\delta^{13} \mathrm{C}$ варьирует в узких пределах - от $-3,1$ до $-2,7 \%$, $\delta^{18} \mathrm{O}$ - от 17,2 до 18,4 \%о (рис. 4). Лишь для образца выветрелого глинистого сланца (№ 81б) отмечено облегчение изотопного состава как по углероду (до $-11,0 \%$ ), так и по кислороду (до 13,9 \%). Также этот образец по результатам геохимических исследований характеризуется существенным снижением (в несколько раз) содержания всех элементов-примесей (кроме U), свидетельствующим об активном проявлении процессов выщелачивания на отдельных участках разреза. В остальных образцах содержания элементов-примесей достаточно выдержаны. Спектры РЗЭ (нормирование относительно хондритовых метеоритов) характеризуются слабым отрицательным наклоном, фиксирующим относительное снижение тяжелых РЗЭ.

\section{Заключение}

Резюмируя вышесказанное можно сделать следующие выводы:

1. Установлено, что воды «Инских источников» умеренно пресные $\mathrm{HCO}_{3} \mathrm{Mg}$-Са состава с величиной общей минерализации от 389 до 536 мг/дм ${ }^{3}$, содержанием кремния 4,14-8,61 мг/дм ${ }^{3}$ и органического углерода $0,3-1,5$ мг/дм ${ }^{3}$. Они характеризуются рН от нейтральных до слабощелочных $(7,1-8,4)$, окислительной геохимической обстановкой c Eh +205,3-+231,8 мB и содержанием

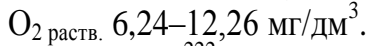

2. Активность ${ }^{222} \mathrm{Rn}$ в «Инских источниках» изменяется в диапазоне от 7 до 149 Бк/дм³ ${ }^{3}$ Природные радионуклиды содержатся в водах $\left(\right.$ мг/дм $\left.{ }^{3}\right):{ }^{238} \mathrm{U}$ $\left(2,83 \cdot 10^{-3}-4,13 \cdot 10^{-3}\right) ;{ }^{232} \mathrm{Th}\left(2,39 \cdot 10^{-6}-1,16 \cdot 10^{-5}\right)$ и ${ }^{226} \operatorname{Ra}\left(3,83 \cdot 10^{-10}-4,93 \cdot 10^{-10}\right) .{ }^{232} \mathrm{Th} /{ }^{238} \mathrm{U}$ отношение в водах составляет $8,85 \cdot 10^{-4}-3,61 \cdot 10^{-3} .{ }^{234} \mathrm{U} /{ }^{238} \mathrm{U}$ в «Инских источниках» составляет от 2,6 до 3,2 , что говорит о неглубокой циркуляции этих вод по сравнению с водами Святого источника в с. ВерхТула, в которых $\gamma=1,3$.

3. По изотопному составу воды имеют инфильтрационное происхождение. Диапазон значений $\delta^{18} \mathrm{O}$ в водах меняется от $-17,1$ до $-16,7 \%$ со значениями $\delta \mathrm{D}$ от $-128,4$ до $-126,2 \%$ и вариацией $\delta^{13} \mathrm{C}_{\mathrm{DIC}}$ в интервале от $-13,1$ до $-10,3 \%$. 


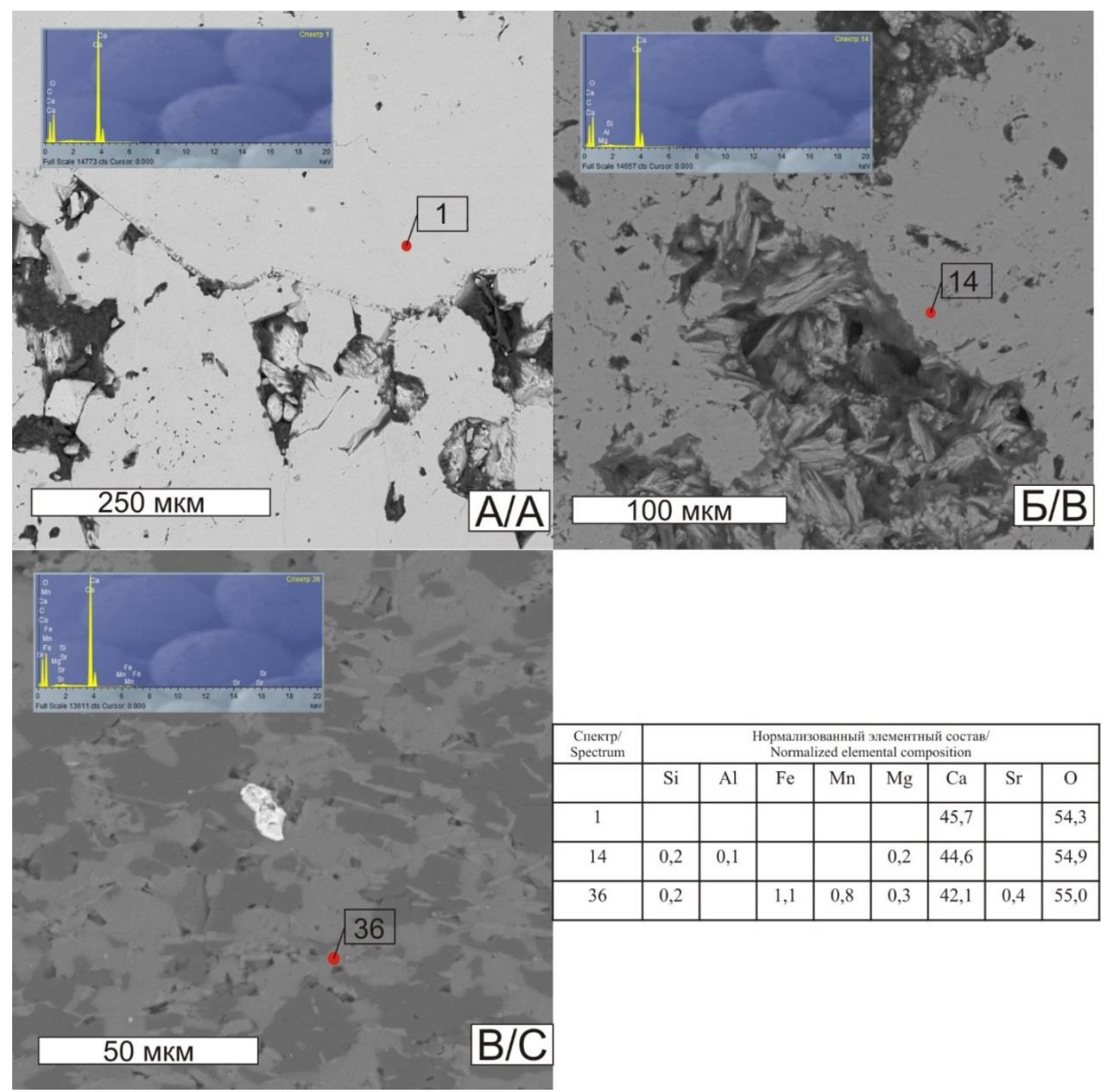

Рис. 3. Состав кальцита вмещзающих пород «Инских источников» по результатам рентгеноспектрального микроанализа: А, Б) известковый туф; В) кальциттизированный сланеи

Fig. 3. Calcite composition of the host rocks of the Inskie springs according to the results of X-ray spectral microanalysis: A, B) calcareous tuff; C) calcified shale

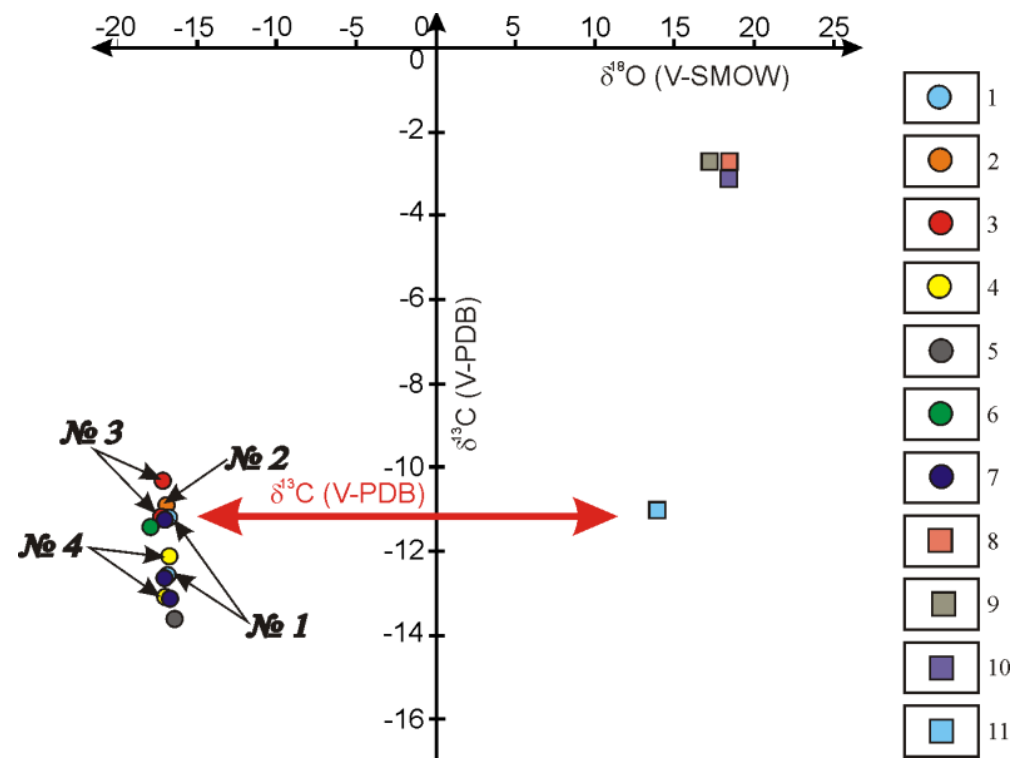

Puc. 4. Изотопный состав $C_{D I C}$ и $O_{6}$ природных водах и породах «Инских источников»: 1 - № 1; 2 № 2; 3 - № 3; 4 - № 4; 5 - колодеи; 6 - скважина; 7 - р. Иня, напротив источников; вмещающие породы: 8 - известковоглинистый сланеи, 9 - известковый туф, 10 - сланеи, 11 - выветрельй сланеи

Fig. 4. Isotopic composition of $C_{D I C}$ and $O$ in natural waters and rocks of the Inskie springs: 1 - no. 1; 2 - no. 2; 3 - no. 3; 4-no. 4; 5 -well; 6 borehole; 7 - Inya river, opposite the spring; host rocks: 8 - calcareous clay shale, 9 - calcareous tuff, 10 - shale, 11 -weathered shale 
Исследование выполнено при финансовой поддержке проекта ФНИ № 0331-2019-0025 и Российского фонда фунда-

\section{СПИСОК ЛИТЕРАТУРЫ}

1. Бахур А.Е. Интерпретация природных и техногенных радиоактивных аномалий в объектах окружающей среды // Разведка и охрана недр. - 2018. - № 7. - С. 58-62.

2. Дойникова О.А., Тарасов Н.Н., Карташов П.М. Урановая минерализация палеодолинных месторождений Витима // Разведка и охрана недр. - 2018. - № 12. - С. 24-30.

3. Четные изотопы урана в поверхностных водах группы малых озер северо-запада Архангельской области / Е.Н. Зыкова, С.Б. Зыков, Е.Ю. Яковлев, Н.С. Ларионов // Успехи современного естествознания. - 2018. - № 4. - С. 114-120.

4. High radionuclides in groundwater of an inland basin from Northwest China: origin and fate / H. Guo, W. Zhao, H. Li, W. Xiu, J. Shen // ACS Earth and Space Chemistry. - 2018. V. 2. - № 11. - P. 1137-1144.

5. Monged M.H.E., Hussein M.T., Khater A.E.M. Elemental and radiological aspects of geothermal springs and nearby soil and sediment of Al-Lith area: concentration and risk assessment // Environmental Earth Sciences. - 2018 - V. 77 - № 427.

6. Hydrogeochemical behavior of uranium and thorium in rock and groundwater samples from southeastern of El Вајі́но Guanajuatese, Guanajuato, Mexico / J.I. Morales-Arredondo, M.A.A. Hernández E. Hernández-Mendiola, R.E. Estrada-Hernández, O.M. Bermea // Environmental Earth Sciences. - 2018. - V. 77 - № 567.

7. Fan W., Hayes K.F., Ellis B.R. Estimating radium activity in shale gas produced brine // Environmental Science \& Technology. 2018. - V. 52. - P. 10839-10847.

8. Поведение изотопов $238 \mathrm{U}, 235 \mathrm{U}, 234 \mathrm{U}$ в процессах выветривания вулканических пород с урановой минерализацией (на примере месторождения Тулукуевское, Восточное Забайкалье) / И.В. Чернышев, В.Н. Голубев, А.В. Чугаев, Г.В. Манджиева, Б.И. Гареев // Петрология. - 2019. - Т. 27. - № 4. - С. 446-467.

9. Plant-soil-water interactions: implications from U-Th-Ra isotope analysis in soils, soil solutions and vegetation (Strengbach CZO, France) / F. Chabaux, P. Stille, J. Prunier, S. Gangloff, D. Lemarchand, G. Morvan, J. Nágrel, E. Pelt, M.-C. Pierret, S. Rihs, A.-D. Schmitt, M. Trémolières, D. Viville // Geochimica et Cosmochimica Acta. - 2019. - V. 259. - P. 188-210.

10. Dhurandhar A.P., Ranjan R. Imaging and integration of hydrogeochemical data for characterization of groundwater quality around Jabalpur, India // Bulletin of Engineering Geology and the Environment. - 2019. - V. 79. - P. 109-131.

11. Environmental assessment of radionuclides levels and some heavy metals pollution along Gulf of Suez, Egypt / H.M. Diab, A. Ramadan, M.H.E. Monged, M. Shahin // Environmental Science and Pollution Research. - 2019. - V. 26. - P. 12346-12358.

12. Embaby A., Redwan M. Sources and behavior of trace elements in groundwater in the South Eastern Desert, Egypt // Environmental Monitoring and Assessment. - 2019. - V. 191. - № 686.

13. Radioactivity of Mt. Etna volcano and radionuclides transfer to groundwater / B. Kozłowska, A. Walencik-Łata, S. Giammanco, G. Immè, R. Catalano, G. Mangano // Annals of geophysics. 2019. - V. 62 - № 5. - VO565.

14. Radium isotopes to trace uranium redox anomalies in anoxic Groundwater / L. Krall, L. Auqué-Sanz, J. Garcia-Orellana, G. Trezzi, E.-L. Tullborg, J. Suksi, D. Porcelli, P. Andersson // Chemical Geology. - 2019. - V. 531. - № 119296.

15. Fractionation of rare earth elements (REEs) and actinides (U and Th) originating from acid thermal water during artificial and natural neutralization processes of surface waters / Y. Ogawa, D. Ishiyama, N. Shikazono, K. Iwane, T. Hoshino, M. Kajiwara, N. Tsuchiya, B. Saini-Eiduka, S.A. Wood // Geochimica et Cosmochimica Acta. - 2019. - V. 249. - P. 247-262.

16. The aqueous chemistry of polonium (Po) in environmental and anthropogenic processes / R. Rama, J. Vaughanb, B. Etschmanna, J. Brugger // Journal of Hazardous Materials. - 2019. - V. 380. № 120725 .

17. Yazdizade B., Jafari H., Bagheri R. Geochemical controls on the distribution of radio-trace elements in groundwater resources of Shir-Kuh granitoid aquifer, central Iran // Hydrology Research. 2019. - V. 50. - № 3. - P. 974-989. ментальных исследований и Правительства Новосибирской области в рамках научного проекта № 19-45-540004.

18. Physico-chemical conditions controlling the radionuclides mobilisation in various granitic environments / A.M. El-Mezayen, E.M. Ibrahim, M.G. El-Feky, S.M. Omar, A.M. El-Shabasy, S.A. Taalab // International Journal of Environmental Analytical Chemistry. - 2020. - P. 1-17.

19. Faraj T., Ragab A., Alfy M.E. Geochemical and hydrogeological factors influencing high levels of radium contamination in groundwater in arid regions // Environmental Research. - 2020. V. 184. - № 109303 .

20. Geochemical controls on dispersion of $U$ and $T h$ in Quaternary deposits, stream water, and aquatic plants in an area with a granite pluton / C. Yu, T. Berger, H. Drake, Z. Song, P. Peltola, M.E. Åström // Science of the Total Environment. - 2019. V. 663. - P. 16-28.

21. Geochemical and isotopic (U, Th) variations in lake waters in the Qinghai Lake Basin, Northeast Qinghai-Tibet Plateau, China: origin and paleoenvironmental implications / P. Zhang, H. Cheng, W. Liu, L. Mo, X. Li, Y. Ning, M. Ji, B. Zong, C. Zhao // Arabian Journal of Geosciences. - 2019. - V. 12. - № 92.

22. Distribution characteristics and influencing factors of uranium isotopes in saline lake waters in the northeast of Qaidam Basin / C. Zhao, P. Zhang, X. Li, Y. Ning, L. Tan, R.L. Edwards, X. Yao, H. Cheng // Minerals. - 2020. - V. 10. - № 74

23. Гусев В.К., Вериго Е.К. Радоновые воды Колывань-Томской складчатой зоны, их использование и охрана // Изменение природных условий под влиянием деятельности человека. 1984. - С. 99-107.

24. Новиков Д.А., Сухорукова А.Ф., Корнеева Т.В. Гидрогеология и гидрогеохимия Заельцовско-Мочищенского проявления радоновых вод (юг Западной Сибири) // Геодинамика и тектонофизика. - 2018. - Т. 9. - № 4. - С. 1255-1274.

25. Новиков Д.А., Деркачев А.С., Сухорукова А.Ф. Гидрогеохимия Заельцовско-Мочищенского проявления радоновых вод // Интерэкспо Гео-Сибирь. - 2019. - Т. 2. - № 1. - С. 125-132.

26. Novikov D.A., Korneeva T.V. Microelements in radon waters of the Zaelsovsky field (the southern part of West Siberia) // Journal of Physics: Conference Series. - 2019. - V. 1172. - № 012096.

27. Корнеева Т.В., Новиков Д.А. Формы миграции химических элементов в радоновых водах месторождения «Горводолечебница» (г. Новосибирск) // Труды Ферсмановской научной сессии ГИ КНЦ РАН. - 2020. - № 17. - С. 287-291.

28. Novikov D.A., Dultsev F.F., Chernykh A.V. Role of water-rock interactions in the formation of the composition of radon waters of the Zaeltsovsky field (the southern part of West Siberia) // Journal of Physics: Conference Series. - 2020. - V. 1451 (1). - № 012007.

29. Первые результаты комплексных изотопногидрогеохимических исследований природных вод Новосибирской городской агломерации / Д.А. Новиков, А.Н. Пыряев, А.В. Черных, Ф.Ф. Дульцев, А.Ф. Сухорукова // Интерэкспо ГЕО-Сибирь - Недропользование. Горное дело. Направления и технологии поиска, разведки и разработки месторождений полезных ископаемых. Экономика. Геоэкология: Материалы XVI международной научной конференции. - Новосибирск, 20-24 апреля 2020. - С. 179-194.

30. Новиков Д.А., Вакуленко Л.Г., Сухорукова А.Ф. Геохимия системы вода-порода проявления слаборадоновых вод «Инские источники» (юг Западной Сибири) // Геологическая эволюция взаимодействия воды с горными породами: Материалы четвертой Всероссийской научной конференции с международным участием. - Улан-Удэ, 17-20 августа 2020. - С. 88-92.

31. Novikov D.A., Dultsev F.F., Kamenova-Totzeva R., Korneeva T.V. Hydrogeological conditions and hydrogeochemistry of radon waters in the Zaeltsovsky-Mochishche zone of Novosibirsk, Russia // Environmental Earth Sciences. - 2021. - V. 80. - № 216.

32. Ферронский В.И., Поляков В.А. Изотопия гидросферы. - М.: Научный мир, 2009. - 632 с

33. Craig H. Isotopic variations in meteoric waters // Science. 1961. - V. 133. - P. 1702-1703.

34. Первые данные по изотопному составу пластовых вод разрабатываемых нефтяных месторождений Новосибирской области / Д.А. Новиков, А.Н. Пыряев, А.В. Черных, Ф.Ф. Дульцев, 
С.В. Рыжкова // Известия Томского политехнического университета. Инжиниринг георесурсов. - 2021. - Т. 332. - № 2. C. 59-72.

35. The GNIP Database. URL: https://nucleus.iaea.org/wiser (дата обращения 10.08.2020).

36. Das A., Krishnaswami S., Bhattacharya S.K.Carbon isotope ratio of dissolved inorganic carbon (DIC) in rivers draining the Deccan Traps, India: Sources of DIC and their magnitudes // Earth and Planetary Science Letters. - 2005. - V. 236. - P. 419-429.

37. Deirmendjian L., Abril G. Carbon dioxide degassing at the groundwater-stream-atmosphere interface: isotopic equilibration and hydrological mass balance in a sandy watershed // Journal of Hydrology. - 2018. - V. 558. - P. 129-143.

38. Лаборатория глобальных наблюдений. URL: http://www.cmdl. noaa.gov/ccgg/iadv/ (дата обращения 10.08.2020).
39. Zhang J., Quay P.D., Wilbur D.O. Carbon isotope fractionation during gas-water exchange and dissolution of $\mathrm{CO} 2$ // Geochimica et Cosmochimica Acta. - 1995. - V. 59. - Iss. 1. - P. 107-114.

40. O, H, C isotope geochemistry of carbonated mineral springs in central Victoria, Australia: sources of gas and water-rock interaction during dying basaltic volcanism / I. Cartwright, T. Weaver, S. Tweed, D. Ahearne, M. Cooper, C. Czapnik, J. Tranter // Journal of Geochemical Exploration. - 2000. V. 69-70. - P. 257-261.

41. Гусев А.И. Геологическое строение и полезные ископаемые района г. Новосибирска. Томск: Изд-во Западно-Сибирского Геолого-гидро-геодезического треста, 1934. - 101 с.

Поступила: 14.08 .2020 2.

\section{Информация об авторах}

Новиков Д.А., кандидат геолого-минералогических наук, заведующий лабораторией гидрогеологии осадочных бассейнов Сибири Института нефтегазовой геологии и геофизики им. А.А. Трофимука СО РАН; доцент кафедры геологии месторождений нефти и газа и кафедры общей и региональной геологии Новосибирского национального исследовательского государственного университета.

Копьлова Ю.Г., кандидат геолого-минералогических наук, главный инженер проблемной научноисследовательской лаборатории гидрогеохимии Инженерной школы природных ресурсов Национального исследовательского Томского политехнического университета.

Вакуленко Л.Г., кандидат геолого-минералогических наук, ведущий научный сотрудник лаборатории седиментологии Института нефтегазовой геологии и геофизики им. А.А. Трофимука СО РАН; доцент Новосибирского национального исследовательского государственного университета.

Сухорукова А.Ф., кандидат геолого-минералогических наук, научный сотрудник лаборатории гидрогеологии осадочных бассейнов Сибири Института нефтегазовой геологии и геофизики им. А.А. Трофимука СО РАН; доцент кафедры общей и региональной геологии Новосибирского национального исследовательского государственного университета.

Пыряев A.H., кандидат химических наук, научный сотрудник лаборатории изотопно-аналитической геохимии Института геологии и минералогии им. В.С. Соболева СО РАН; ассистент кафедры химической и биологической физики Новосибирского национального исследовательского государственного университета.

Максимова $\boldsymbol{A}$.A., студент Новосибирского национального исследовательского университета.

Дульцев Ф.Ф., научный сотрудник лаборатории гидрогеологии осадочных бассейнов Сибири Института нефтегазовой геологии и геофизики им. А.А. Трофимука СО РАН.

Черных $\boldsymbol{A}$.В., научный сотрудник лаборатории гидрогеологии осадочных бассейнов Сибири Института нефтегазовой геологии и геофизики им. А.А. Трофимука СО РАН. 
UDC 556.332.52(571.1)

\section{ISOTOPE GEOCHEMICAL FEATURES OF OCCURRENCE OF LOW-RADON WATERS «INSKIE SPRINGS» (SOUTH-WESTERN SIBERIA)}

Dmitry A. Novikov ${ }^{1,2}$, NovikovDA@ipgg.sbras.ru

Yulia G. Kopylova ${ }^{3}$, unpc_voda@mail.ru

Lyudmila G. Vakulenko1,2, Vakylenkolg@ipgg.sbras.ru

Anna F. Sukhorukova1,2, SukhorukovaAF@ipgg.sbras.ru

\author{
Aleksandr N. Pyrayevi,2, \\ pyrayev@igm.nsc.ru
}

Anastasia A. Maksimova², rock.nastaya64@gmail.com

Fedor F. Dultsev ${ }^{1}$, DultsevFF@ipgg.sbras.ru

\section{Anatoliy V. Chernykh ${ }^{1}$,} ChernykhAV@ipgg.sbras.ru

1 Trofimuk Institute of Petroleum Geology and Geophysics SB RAS,

3/6, Koptyug avenue, Novosibirsk, 630090, Russia.

2 Novosibirsk State University,

1, Pirogov street, Novosibirsk, 630090, Russia.

3 National Research Tomsk Polytechnic University, 30, Lenin avenue, Tomsk, 634050, Russia.

4 Institute of Geology and Mineralogy SB RAS,

3, Koptyug avenue, Novosibirsk, 630090, Russia

The relevance of the research lies in obtaining the first isotope-geochemical data on natural waters and host rocks of the «Inskie springs» occurrence of low-radon waters.

The aim of the research is to study the peculiarities of chemical composition of natural waters and water-bearing rocks and obtain the first information on the total $\alpha$ - and $\beta$-activity of natural waters, the activity of ${ }^{222} \mathrm{Rn}$ and the isotopic composition of $\delta \mathrm{D}, \delta^{18} \mathrm{O}, \delta^{13} \mathrm{C},{ }^{234} \mathrm{U},{ }^{238} \mathrm{U}$, ${ }^{226} \mathrm{Ra}$ and ${ }_{228} \mathrm{Ra}$.

Methods. Sampling was carried out in accordance with generally accepted techniques. Laboratory study of the chemical composition by titrimetry, ion chromatography, inductively coupled plasma mass spectrometry was carried out at the Problem Research Laboratory of Hydrogeochemistry of the TPU School of Natural Resources. The analysis of the complex of isotopic ratios $\delta D, \delta^{18} \mathrm{O}, \delta^{13} C_{D I C}$ of waters and dissolved inorganic carbon was carried out at the Center for Collective Use of the IGM SB RAS using the Isotope Ratio Mass Spectrometer FinniganTM MAT 253. Data on the total á- and $\beta$-activity of natural waters, as well as the activities of ${ }^{234} \mathrm{U},{ }^{238} \mathrm{U},{ }^{226} \mathrm{Ra} u{ }^{228} \mathrm{Ra}$ were obtained using gamma and alpha spectrometry (after preliminary radiochemical sample preparation).

Results. In 2019, $35 \mathrm{~km}$ from Novosibirsk, far from the known granite massifs, the "Inskie springs» occurrence of low-radon waters was discovered, referring to the waters of the regional fracture zone. The work presents the first results of their geochemical studies. The waters are moderately fresh $\mathrm{HCO}_{3} \mathrm{Mg}$-Ca with a total mineralization from 389 to $536 \mathrm{mg} / \mathrm{dm}^{3}$ with a silicon content of 4,14-8,61 mg/dm3. They are characterized by $\mathrm{pH}$ from neutral to slightly alkaline (7,1-8,4), oxidative geochemical environment with Eh $+205,3-+231,8 \mathrm{mV}$

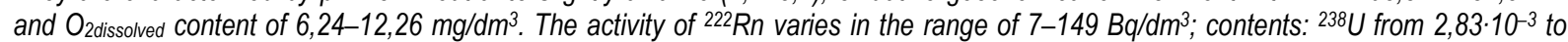
$4,13 \cdot 10^{-3} \mathrm{mg} / \mathrm{dm}^{3}$ and ${ }^{232} \mathrm{Th}$ from $2,39 \cdot 10^{-6}$ to $1,16 \cdot 10^{-5} \mathrm{mg} / \mathrm{dm}^{3}$. According to the isotopic composition, the origin of water is infiltration. The range of $\delta^{18} \mathrm{O}$ values in waters varies from $-17,1$ to $-16,7 \%$ with $\delta D$ values from $-128,4$ to $-126,2 \%$ and $\delta^{13} \mathrm{C}$ variation is in the range of $-13,1$ to $-10,3 \%$. The host rocks are dark gray (to black) shales, sometimes gray, with a small admixture of silty and sandy-silty material. The isotopic composition of calcite in the host rocks is characterized by similar values: $\delta^{13} \mathrm{C}$ varies from $-3,1$ to $-2,7 \%, \delta^{18} \mathrm{O}-$ from 17,2 to $18,4 \%$. Weathered clay shales are characterized by lower contents of $\delta^{13} \mathrm{C}$ (up to $-11,0 \%$ ) and $\delta^{18} \mathrm{O}$ (up to $13,9 \%$ ). Also, according to the results of geochemical studies, these samples are characterized by a significant decrease in the content of all trace elements (except for $U$ ), which indicates active interaction of waters with the host rocks.

\section{Key words:}

Radon waters, stable isotope, uraniumisotope ratio, uranium, radium, radon, new occurrence of radon waters «Insky spring», Novosibirsk urban agglomeration, Western Siberia.

The research was financially supported by the FSR no. 0331-2019-0025 and the Russian Foundation for Basic Research as part of the scientific project no. 19-45-540004.

\section{REFERENCES}

1. Bakhur A.E. Interpreting technogenic and nontechnogenic radioactive anomalies in environmental objects. Prospect and protection of mineral resources, 2018, no. 7, pp. 58-62. In Rus.

2. Doynikova O.A., Tarasov N.N., Kartashov P.M. Uranium mineralization of Vitim paleovalleys deposits. Prospect and protection of mineral resources, 2018, no. 12, pp. 24-30. In Rus.
3. Zykova E.N., Zykov S.B., Yakovlev E.Yu., Larionov N.S. Evolutionary isotopes of uranium in surface waters of the group of small lakes of the northwest of the Arkhangelsk region. Advances in current natural sciences, 2018, no. 4, pp. 114-120. In Rus.

4. Guo H., Zhao W., Li H., Xiu W., Shen J. High radionuclides in groundwater of an inland basin from Northwest China: Origin and fate. ACS Earth and Space Chemistry, 2018, vol. 2, no. 11, pp. 1137-1144. 
5. Monged M.H.E., Hussein M. T., Khater A.E.M. Elemental and radiological aspects of geothermal springs and nearby soil and sediment of Al-Lith area: concentration and risk assessment. Environmental Earth Sciences, 2018, vol. 77, no. 427.

6. Morales-Arredondo J.I., Hernández M.A.A., Hernández-Mendiola E. Estrada-Hernández R.E., Bermea O.M. Hydrogeochemical behavior of uranium and thorium in rock and groundwater samples from southeastern of El Bajíно Guanajuatese, Guanajuato, Mexico. Environmental Earth Sciences, 2018, vol. 77, no. 567.

7. Fan W., Hayes K.F., Ellis B.R. Estimating radium activity in shale gas produced brine. Environmental Science \& Technology, 2018, vol. 52, pp. 10839-10847.

8. Chernyshev I.V., Golubev V.N., Chugaev A.V., Mandzhieva G.V. Gareev B.I. Behavior of the ${ }^{238} \mathrm{U},{ }^{235} \mathrm{U}$, and ${ }^{234} \mathrm{U}$ isotopes at weathering of volcanic rocks with u mineralization: a case study at the Tulukuevskoe deposit, eastern Transbaikalia. Petrology, 2019, vol. 27, no. 4, pp. 407-424. In Rus.

9. Chabaux F., Stille P., Prunier J., Gangloff S., Lemarchand D., Morvan G., Nágrel J., Pelt E., Pierret M.-C., Rihs S., Schmitt A.-D., Trémolières M., Viville D. Plant-soil-water interactions: Implications from U-Th-Ra isotope analysis in soils, soil solutions and vegetation (Strengbach CZO, France). Geochimica et Cosmochimica Acta, 2019, vol. 259, pp. 188-210.

10. Dhurandhar A.P., Ranjan R. Imaging and integration of hydrogeochemical data for characterization of groundwater quality around Jabalpur, India. Bulletin of Engineering Geology and the Environment, 2019, vol. 79, pp. 109-131.

11. Diab H.M., Ramadan A., Monged M.H.E., Shahin M Environmental assessment of radionuclides levels and some heavy metals pollution along Gulf of Suez, Egypt. Environmental Science and Pollution Research, 2019, vol. 26, pp. 12346-12358.

12. Embaby A., Redwan M Sources and behavior of trace elements in groundwater in the South Eastern Desert, Egypt. Environmental Monitoring and Assessment, 2019, vol. 191, no. 686.

13. Kozłowska B., Walencik-Łata A., Giammanco S., Immè G., Catalano R., Mangano G. «Radioactivity of mt. Etna volcano and radionuclides transfer to groundwater». Annals of geophysics, 2019, vol. 62 , no. 5 , VO565.

14. Krall L., Auqué-Sanz L., Garcia-Orellana J., Trezzi G., Tullborg E.-L., Suksi J., Porcelli D., Andersson P. Radium isotopes to trace uranium redox anomalies in anoxic Groundwater. Chemical Geology, 2019, vol. 531, no. 119296.

15. Ogawa Y., Ishiyama D., Shikazono N., Iwane K., Hoshino T., Kajiwara M., Tsuchiya N., Saini-Eiduka B., Wood S.A. Fractionation of rare earth elements (REEs) and actinides ( $\mathrm{U}$ and Th) originating from acid thermal water during artificial and natural neutralization processes of surface waters. Geochimica et Cosmochimica Acta, 2019, vol. 249, pp. 247-262.

16. Rama R., Vaughanb J., Etschmanna B., Brugger J. The aqueous chemistry of polonium (Po) in environmental and anthropogenic processes. Journal of Hazardous Materials, 2019, vol. 380, no. 120725 .

17. Yazdizade B., Jafari H., Bagheri R. Geochemical controls on the distribution of radio-trace elements in groundwater resources of Shir-Kuh granitoi aquifer, central Iran. Hydrology Research, 2019, vol. 50, no. 3, pp. 974-989.

18. El-Mezayen A.M., Ibrahim E.M., El-Feky M.G., Omar S.M., El-Shabasy A.M., Taalab S.A. Physico-chemical conditions controlling the radionuclides mobilisation in various granitic environments. International Journal of Environmental Analytical Chemistry, 2020, pp. 1-17.

19. Faraj T., Ragab A., Alfy M.E. Geochemical and hydrogeological factors influencing high levels of radium contamination in groundwater in arid regions. Environmental Research, 2020, vol. 184 , no. 109303.

20. Yu C., Berger T., Drake H., Song Z., Peltola P., Åström M.E. Geochemical controls on dispersion of $\mathrm{U}$ and $\mathrm{Th}$ in Quaternary deposits, stream water, and aquatic plants in an area with a granite pluton. Science of the Total Environment, 2019, vol. 663, pp. 16-28.

21. Zhang P., Cheng H., Liu W., Mo L., Li X., Ning Y., Ji M., Zong B., Zhao C. Geochemical and isotopic (U, Th) variations in lake waters in the Qinghai Lake Basin, Northeast Qinghai-Tibet Plateau, China: origin and paleoenvironmental implications. Arabian Journal of Geosciences, 2019, vol. 12, no. 92.
22. Zhao C., Zhang P., Li X., Ning Y., Tan L., Edwards R.L., Yao X., Cheng H. Distribution Characteristics and Influencing Factors of Uranium Isotopes in Saline Lake Waters in the Northeast of Qaidam Basin. Minerals, 2020, vol. 10, no. 74

23. Gusev V.K., Verigo E.K. Radonovye vody Kolyvan-Tomskoy skladchatoy zony, ikh ispolzovanie i okhrana [Radon waters of the Kolyvan-Tomsk folded zone, their use and protection]. Izmenenie prirodnykh usloviy pod vliyaniyem deyatelnosti cheloveka, 1984, pp. 99-107.

24. Novikov D.A., Sukhorukova A.F., Korneeva T.V. Hydrogeology and hydrogeochemistry of the Zaeltsovsko-Mochishchensky zone of radon waters in the southern West Siberia. Geodynamics \& Tectonophysics, 2018, vol. 9, no. 4, pp. 1255-1274. In Rus.

25. Novikov D.A., Derkachev A.S., Sukhorukova A.F. Hydrogeochemistry of the Zaeltsovsky-Mochishche field of radon waters. Interexpo GEO-Siberia, 2019, vol. 2, no. 1, pp. 125-132. In Rus.

26. Novikov D.A., Korneeva T.V. Microelements in radon waters of the Zaelsovsky field (the southern part of West Siberia). Journal of Physics: Conference Series, 2019, vol. 1172, no. 012096.

27. Korneeva T.V., Novikov D.A. Migration forms of chemical elements in radon waters of the Gorvodolechebnitsa field, Novosibirsk. Proceedings of the Fersmanov Scientific Session of the State Institute of the KSC RAS, 2020, no. 17, pp. 287-291. In Rus.

28. Novikov D.A., Dultsev F.F., Chernykh A.V. Role of water-rock interactions in the formation of the composition of radon waters of the Zaeltsovsky field (the southern part of West Siberia). Journal of Physics: Conference Series, 2020, vol. 1451 (1), no. 012007.

29. Novikov D.A., Pyryaev A.N., Chernykh A.V., Dultsev F.F., Sukhorukova A.F. Pervye rezultaty izotopno-gidrogeokhimicheskikh issledovany prirodnykh vod Novosibirskoy gorodskoy aglomeratsii [The first results of integrated isotope-hydrogeochemical studies of natural waters in the Novosibirsk urban agglomeration]. Interexpo GEO-Sibir. Nedropolzovanie. Gornoe delo. Napravleniya i tekhnologii poiska, razvedki i razrabotki mestorozhdeniy poleznykh iskopaemykh. Ekonomika. Geoekologiya. Materialy XVI mezhdunarodnoy nauchnoy konferentsii [Interexpo GEO-Siberia. Subsoil use. Mining. Directions and technologies of prospecting, exploration and development of mineral deposits. Economy. Geoecology. Proc. of the XVI International Scientific Conference]. Novosibirsk, April 20-24, 2020. pp. 179-194.

30. Novikov D.A., Vakulenko L.G., Sukhorukova A.F. Geokhimiya sistemy voda-poroda proyavleniya slaboradonovykh vod «Inskie isrochniki» [Geochemistry of the water-rock system of weak hydro-radon occurrence «Inskie springs» (south of Western Siberia)]. Geologicheskaya evolyutsiya vzaimodeystviya vody s gornymi porodami. Materialy chetvertoy Vserossiyskoy nauchnoy konferentsii s mezhdunarodnym uchastiem [Water-rock interaction: geological evolution. Proc. of the fourth All-Russian scientific conference with international participation]. Ulan-Ude, 17-20 August 2020. pp. 88-92.

31. Novikov D.A., Dultsev F.F., Kamenova-Totzeva R., Korneeva T.V. Hydrogeological conditions and hydrogeochemistry of radon waters in the Zaeltsovsky-Mochishche zone of Novosibirsk, Russia. Environmental Earth Sciences, 2021, vol. 80, no. 216.

32. Ferronsky V.I., Polyakov V.A. Izotopiya gidrosfery [Isotopy of the hydrosphere]. Moscow, Nauchny mir Publ., 2009. 632 p.

33. Craig H. Isotopic variations in meteoric waters. Science, 1961, vol. 133, pp. 1702-1703.

34. Novikov D.A., Pyrayev A.N., Chernykh A.V., Dultsev F.F., Ryzhkova S.V. The first data on the isotopic composition of stratal waters of the developed oil fields in Novosibirsk region. Bulletin of the Tomsk Polytechnic University. Geo Assets Engineering, 2021, vol. 332, no. 2, pp. 59-72. In Rus.

35. The GNIP Database. Available at: https://nucleus.iaea.org/wiser (accessed 10 August 2020)

36. Das A., Krishnaswami S., Bhattacharya S.K. Carbon isotope ratio of dissolved inorganic carbon (DIC) in rivers draining the Deccan Traps, India: sources of DIC and their magnitudes. Earth and Planetary Science Letters, 2005, vol. 236, pp. 419-429.

37. Deirmendjian L., Abril G. Carbon dioxide degassing at the groundwater-stream-atmosphere interface: isotopic equilibration and hydrological mass balance in a sandy watershed. Journal of Hydrology, 2018, vol. 558, pp. 129-143. 
38. Laboratoriya globalnykh nablyudeny [Global Monitoring Laboratory]. Available at: http://www.cmdl.noaa.gov/ccgg/iadv/ (accessed 10 August 2020).

39. Zhang J., Quay P.D., Wilbur D.O. Carbon isotope fractionation during gas-water exchange and dissolution of $\mathrm{CO}_{2}$. Geochimica et Cosmochimica Acta, 1995, vol. 59, Iss. 1, pp. 107-114.

40. Cartwright I., Weaver T., Tweed S., Ahearne D., Cooper M., Czapnik C., Tranter J. O, H, C isotope geochemistry of carbonated mineral springs in central Victoria, Australia: sources of gas and water-rock interaction during dying basaltic volcanism. Journal of Geochemical Exploration, 2000, vol. 69-70, pp. 257-261.

41. Gusev A.I. Geologicheskoe stroyenie i poleznye iskopayemye rayona g. Novosibirska [Geological structure and minerals of the region of Novosibirsk]. Tomsk, West Siberian Geological-HydroGeodetic Trust Publ., 1934. 101 p.

Received: 14 August 2020.

\section{Information about the authors}

Dmitry A. Novikov, Cand. Sc., head of the laboratory, Trofimuk Institute of Petroleum Geology and Geophysics of Siberian Branch of Russian Academy of Sciences; associate professor, Novosibirsk State University.

Yulia G. Kopylova, Cand. Sc., senior scientific laboratory, National Research Tomsk Polytechnic University.

Lyudmila G. Vakulenko, leading researcher, Trofimuk Institute of Petroleum Geology and Geophysics of Siberian Branch of Russian Academy of Sciences; associate professor, Novosibirsk State University.

Anna F. Sukhorukova, Cand. Sc., researcher, Trofimuk Institute of Petroleum Geology and Geophysics of Siberian Branch of Russian Academy of Sciences; associate professor, Novosibirsk State University.

Aleksandr N. Pyrayev, Cand. Sc., researcher, Institute of Geology and Mineralogy of SB of RAS, assistant, Novosibirsk State University.

Anastasia A. Maksimova, student, Novosibirsk State University.

Fedor F. Dultsev, researcher, Trofimuk Institute of Petroleum Geology and Geophysics of Siberian Branch of Russian Academy of Sciences.

Anatoliy V. Chernykh, researcher, Trofimuk Institute of Petroleum Geology and Geophysics of Siberian Branch of Russian Academy of Sciences. 